\title{
The relationship between visit time management and patient's family satisfaction in the intensive care unit
}

\author{
Yuni Sudaryanto ${ }^{1}$, Jebul Suroso ${ }^{2}$ \\ ${ }^{1,2}$ Sciences, Muhammadiyah University of Purwokerto
}

\begin{abstract}
ARTICLE INFO
Article history:

Received: August 9, 2020

Revised: August 20, 2020

Accepted: August 30, 2020

\section{Keywords:}

Intensive Care Unit, visitingtime management, family, satisfaction

ABSTRACT

The Intensive Care Unit is an independent hospital part (an installation under the service director) with special staff and equipment for the observation, treatment and therapy of patients who suffer from life-threatening diseases, injuries or complications. Or potentially life-threatening. The policy of Intensive Care Unit by limiting the visiting times aims to maximize the care for patients with critical conditions. The satisfaction of the patient family is at the center point recognized as a measure of the quality of care services in the Intensive Care Unit. The purpose of this study was to determine the relationship between visiting time management and the satisfcation of the patient family It used a descriptive quantitative method, a correlation study with a cross sectional design. The sampling technique was total sampling with the respondents of the families, 40 respondents. They were then analyzed using Spearman Rank correlation statistical technique. The results of the Spearman rank analysis gave a $p$ value of $0.044<0.05$, meaning there is a significant relationship between visiting-time management and the satisfaction of family patients.In conclusion he management of visiting-time can be an influential factor in determining the satisfaction of the patient family over the hospital services.
\end{abstract}

This work is licensed under a Creative Commons Attribution 4.0 International License.

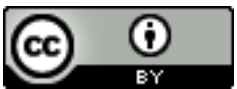

\section{Corresponding Author:}

Name of Corresponding Author,

Faculty of Health Sciences, Muhammadiyah University of Purwokerto

J1.Letjen Soepardjo Roestam Km 7 PO.Box 229 Purwokerto 53181

Email: yusmul1@gmail.com

\section{INTRODUCTION}

Critical patients need intensive care for close and continous monitoring her/his physiological condition due to decreased organ function. The Intensive Care Unit is part of a hospital with a critical service category in addition to surgical and emergency departments [1]. This requires hospitals to implement special policies on the visiting times, including the length, and the number visitors. The policy of the Intensive Care Unit on visiting times aims to maximize the care for patients with critical conditions. It includes the open and closed visiting time policy [2]. Most hospitals in Indonesia implement a closed time policy at the Intensive Care Unit, namely by setting a limit on visiting times to around 1-2 hours per visit.

In the research of Khaleghparast, it was found that 16 of 17 hospitals implemented the policy. The visiting time was only 2-3 times a day and each visit was limited to 30-45 minutes. In France, the application of visiting hours at the hospital varies between 263 ICU rooms, where 34 ICUs have no visiting hours, 218 ICUs have limited visiting hours ( $<4$ hours a day) and 11 ICUs have unlimited visiting hours [3]. Meanwhile, visiting times greatly affect services in the ICU, especially satisfaction for the patient's family. Family satisfaction is at the center point recognized as a measure of the quality of care services in the Intensive Care Unit. Thus, family members often determine the satisfaction of services provided, as well as the overall critical care experience, meaning the satisfaction can be measured through the perceptions of family members that determine whether patients receive high quality care regardless of clinical outcomes. Zouka's finding has proved that the patient's family satisfaction is influenced by $81 \%$ of the patient's attention and management, 
$89 \%$ of the fulfillment of information needs, $73 \%$ by participation in decision making, $6 \%$ by emotional support, $28 \%$ of communication frequency, and $47 \%$ by spatial atmosphere wait and visit times [4].

The hospital accreditation standard in 2012 rules that the satisfaction of family and patient is an indicator of the quality of managerial services. The hospital has to conduct a survey for this [5]. The satisfying nursing services are those that can provide the quality and quality of health services [6]. The patient satisfaction refers to several dimensions of service quality, namely reliability, responsiveness, assurance, empathy, and tangiability. States that ICU patient familys dissatisfaction is caused by the low communication frequency by nurses, skills and competence of nurses, intensive care environment and patient visiting hours. The family has an important and integral role in determining how to provide nursing care so that it can increase the quality of care, satisfaction of patients and families. The involvement of patients and families in service to patients is very necessary to improve the health status of the patients and increase the care efficiency [7]. However, in most Indonesian hospitals in Indonesia, the presence of families is still limited, especially in the ICU room.

A research in South Africa found that an open visit policy can reduce the risk of disease complications, decrease anxiety levels and increase patient family satisfaction. Another study revealed that the limitation of time to visit patients in the ICU room needs to be revised in relation to satisfaction by the authorities concerned, health staff and also considering cultural aspects and patient rights [8]. Based on the phenomena in the field, the management of visiting time greatly affects the level of satisfaction of the patient's family. The management of visiting times includes the provision of services and restrictions on good visiting times; health workers incharged participate and are involved in the management of visiting times, in accordance with the management of visiting times at the Intensive Care Unit of Banyumas Hospital, i.e., 1-2 hours. The policy of limiting visittime for the patients treated in the Intensive Care Unit room is an issue to consider in providing the care.

\section{RESEARCH METHOD}

The method in this study is a descriptive quantitative. This study is a correlation study with a cross sectional design. The sampling technique in this study was total sampling; the respondents were the families of the patients in the Intensive Care Unit of Banyumas Hospital. There were 40 repondents. The data were obtained from questionnaire with 24 questions. The analysis of the data employed the Spearman Rank correlation.

\section{RESULTS AND DISCUSSIONS}

The result of the univariate test showed that the majority of respondents $(47.5 \%)$ felt that the level of management of visit time was moderate and few of them (15.00\%) thought it as high (15.0\%); most of the respondents $(45.0 \%)$ had a very high level of satisfaction and fewer respondents $(25.0 \%)$ were not satisfied. The Spearman rank analysis test obtained a p value of $0.044<0.05$, which means that there is a relationship between visiting time management and the satisfaction of patient family in the Intensive Care Unit of Banyumas Hospital.

Table 1. Characteristics of respondent $(\mathrm{n}=40)$

\begin{tabular}{lc}
\hline Characteristics & Resuts \\
\hline Age & $39,05 \pm 10,741$ \\
& Min-max 18-59 \\
Gender & $22(55,0 \%)$ \\
Male & $18(45,0 \%)$ \\
Female & \\
Education & $13(32,5 \%)$ \\
Elementary School & $12(30,0 \%)$ \\
Junior High School & $10(25,0 \%)$ \\
Senior High School & $3(7,5 \%)$ \\
Diploma & $2(5,0 \%)$ \\
Bachelor & \\
Occupation & $11(27,5 \%)$ \\
Enteupreneur & $11(27,5 \%)$ \\
Unemployed & $0(0 \%)$ \\
Civil Servants/retired & $9(22,5 \%)$ \\
Farmer & $0(0 \%)$ \\
Government employees & $9(22,5 \%)$ \\
Housewife & \\
Ascent to & $19(47,5 \%)$ \\
2 day's & $18(45,0 \%)$ \\
3 day's &
\end{tabular}

Proceeding homepage: https://conferenceproceedings.ump.ac.id/index.php/pshms/issue/view/1 


\begin{tabular}{ll}
\hline$>3$ day's $3(7,5 \%)$ \\
\hline
\end{tabular}

Table 2. Distribution of visit-time management and family satisfaction

\begin{tabular}{lcc}
\hline \multicolumn{1}{c}{ Variable } & Frequency & Procentage \\
\hline Visit-time management & 15 & $37,5 \%$ \\
$\quad$ Loose & 19 & $47,5 \%$ \\
Moderate & 6 & $15,0 \%$ \\
Strict & & \\
Satisfaction level & & \\
$\quad$ Not satisfied & 10 & $25,0 \%$ \\
Satisfied & 12 & $30,0 \%$ \\
Very satisfied & 18 & $45,0 \%$ \\
\hline
\end{tabular}

Table 3. Correlation of visit-time management and the satisfaction of the patientsfamily in the ICU

\begin{tabular}{|c|c|c|c|c|c|c|c|c|c|c|}
\hline \multirow{3}{*}{$\begin{array}{c}\text { Visit-time } \\
\text { management }\end{array}$} & \multicolumn{8}{|c|}{ Satisfaction level } & \multirow[t]{3}{*}{ p-value } & \multirow[t]{2}{*}{ Rho } \\
\hline & \multicolumn{2}{|c|}{ Not satisfied } & \multicolumn{2}{|c|}{ Satisfied } & \multicolumn{2}{|c|}{$\begin{array}{c}\text { Very } \\
\text { satisfied }\end{array}$} & \multicolumn{2}{|c|}{ Total } & & \\
\hline & $\mathbf{f}$ & $\%$ & f & $\%$ & $\mathbf{f}$ & $\%$ & n & $\%$ & & \\
\hline Loose & 4 & 26,7 & 8 & 53,3 & 3 & 20,0 & 15 & 100 & 0.044 & 0,320 \\
\hline Moderate & 6 & 31,6 & 2 & 10,5 & 11 & 57,9 & 19 & 100 & & \\
\hline Strict & 0 & 0 & 2 & 33,3 & 4 & 66,7 & 6 & 100 & & \\
\hline
\end{tabular}

In this study, it is known that the the age of the respondents is 39.05 years in average, with the youngest of 18 years old and the oldest of 59 years old. Their age affects their level of satisfaction explained that the older a person is, the more satisfaction they will have; the younger a person or those in productive age tends to be more demanding and expect more about the ability of basic health services and they tend to be more critical. Based on gender, most of them $(55.0 \%)$ were male. Explained that satisfaction is strongly influenced by gender. Men are more objective in assessing with the aim of protecting or intervening, and providing a sense of security for their families. Men also tend to influence women more in giving opinions or considerations to do something.

Based on their education, most of them $(32.5 \%)$ have primary school education. The research shows that the patients with lower education are more likely to be satisfied than those with higher education. The later tend to demand more services and ask more frequently [9]. Based on their occupation, most of them (27.5\%) work as entrepreneurs and laborers. States that working community groups tend to be influenced by the work environment as well as the family environment. This has something to do with the theory which states that someone who works tends to be more demanding or criticizing over the services they are dissatisfied with, compared to the unemployed. Based on the length of the stay, most patients in the ICU (47.5\%) were treated for 2 days. The length of treatment is decided by the medical team, doctors and nurses, by considering the patient's physical condition, type of disease, and patient stability in receiving treatment and care from the hospital. In the management level of visit time of the family, the results showed that most respondents (47.5\%) percieved the level of visit-time management at the ICU at Banyumas Hospital was moderate. Visit time management is the planning and the organization of an effective visit-time. It is determined based on the policy of a hospital. Clear limitations on visiting times in critical care areas are decided based on nurse tradition and choice [10].

The limitation of visit time for the patients in Intensive Care Unit has significant implications for the health and safety of the patient and his/her family. This is in accordance with a notion saying that the policy to limit visiting times is determined by the hospital to improve its services for patient [11]. In term of the satisfaction of the patient's family, the results showed that most of them (45.0\%) had been very satisfied. It can be said that most of them thought that the visit management of the hospital has met their expectations. This is in line with Supriyanto stating that the satisfaction of the patient's family will be achieved as their expection has been well-fulfilled [12]. This finding is just similar to another study which indicated 50\% of the respondents were satisfied with the service in the ICU Room at Permata Medika Hospital [13]. The satisfaction of the patients family is influenced by several internal factors, namely age, gender, and education, and external factors, including product characteristics, price, service, facilities, image, and communication. Also states that family satisfaction of ICU patients is influenced by the following factors, $81 \%$ by attention, concern and management over the patient, $89 \%$ by the information needs fulfilling, $73 \%$ by participation in decision making, $6 \%$ by emotional support, $28 \%$ by communication frequency, and $47 \%$ by the atmosphere in the waiting room. 
The results showed that there was a relationship between visiting time management and satisfaction of the family in the Intensive Care Unit of the Banyumas Regional General Hospital (p value of 0.044). This is in line with another study which has proved that there is a relationship between the quality of nursing services and the satisfaction of the patient's family in the ICU room of Permata Medika Hospital Semarang. It also supports Fumagallis finding, which shows that ICU rooms implementing a limited visit policy had less bacterial contamination and infections (pneumonia, urinary tract infections, Common infections). Good service quality includes the physical appearance of the room, good nurses, their reliability in providing services, their good response to patients, the provision of their guaranteed services, their empathy of to patients and his/her families, and good management of visiting times. All of these will have good impact on their satisfaction. The results of this study show that the policy of limited visit ruling the hospital visits, from the perspective of the patient's family, has been enforced for three reasons: 1) it is the form of rule implementation, 2) it is to avoid confusion or mistakes and it is a way for being professional at work. This is in line which explains that $35 \%$ of patients prefer to have visitors only once to twice a day (limited visiting time). This is viewed to be one of the advantages of limited visits as it prevents complications in the patient. Visiting patients is a positive and effective strategy to help patients and their families better adapt to the stress and the crisis during their stay in the ICU.

The family satisfaction in the Intensive Care Unit is a form of family comfort in accompanying the patients, which leads to various positive responses from the family to the care services provided. Family satisfaction generates an optimistic family response that increases the role and function of the family in providing support to family members being treated in the ICU. Thus, the family-based nursing can be provided comprehensively and holistically. Describes a quality of health services (service quality) refers to five dimensions of service quality to achieve satisfaction, i.e. Reliability, responsiveness, empathy, assurance, and tangible. These play an important role in the service industry such as the health service of a hospital. The patient's family will feel satisfied if they get good service they have expected.

\section{CONCLUSION}

Visit time management can be an influencing factor in determining the service satisfaction of the patient family. This includes the familys support the services to improve the patient care.

\section{REFERENCES}

[1] Depkes RI, Profil Kesehatan Republik Indonesia Tahun 2012, 2012.

[2] S. Khaleghparast, "Visiting Hours Policies In Intensive Care Unit,," 2016.

[3] S. Lavergne, S. Hauchard, S. Dray and M. Baill, "Survey of Caregiver Opinions on the Practicalities of Family centered Care in Intensive Care Units," Journal of Clinical Nursing, vol. 21, 2011.

[4] M. Zouka, Myrou and Anastasiou, "Family Satisfaction in the ICU: A b-month Experience.," Care, vol. 18 , no. $27,2014$.

[5] Santoso and Singgih, Statistik Multifariat,Edisi Revisi,Konsep dan Aplikasi dengan SPSS, Jakarta: Elex Media Computindo, 2014.

[6] Nursalam, Manajemen keperawatan aplikasi dan paktek professional edisi ketiga, Jakarta: Salemba Medika, 2011.

[7] R. Pelzang, "Time to learn : understanding patient-centered care," British Journal Of Nursing, vol. 19, no. (14), 2010.

[8] S. Haghbine, Z. Tayebi , A. Abasiyan and T. Farkhondeh, "Visiting hour polices in intensive care units, Southern Iran. Middle-East," Journal ofScientific Reasearch, vol. 14, no. 3, 2013.

[9] S. Panggato , B. Lampus and W. Kaunang, "Tingkat Kepuasan Pasien Rawat Jalan terhadap Ketepatan Waktu Pelayanan Oleh Tenaga Kesehatan di Puskesmas Ranotana Weru Kecamatan Wanea Kota Manado," 2011.

[10] K. D. Olsen, E. Dysvik and B. S. Hansen, "Intensive and Critical Care Nursing," vol. 25, pp. 190198, 2009.

[11] E. Setyani, "Persepsi Keluarga Tentang Waktu Berkunjung di Intensive Care Unit," Universitas Diponegoro, Semarang, 2017.

[12] Supriyanto and Ernawaty, Pemasaran Industri Jasa Kesehatan, Yogyakarta: ANDI, 2010.

[13] D. Retnaningsih, D. N. Aini and Yulianti, "Kepuasan keluarga pasien diruang ICU Rumah Sakit Permata Medika Semarang," Jurnal Stikes Kusuma Husada, 2017. 